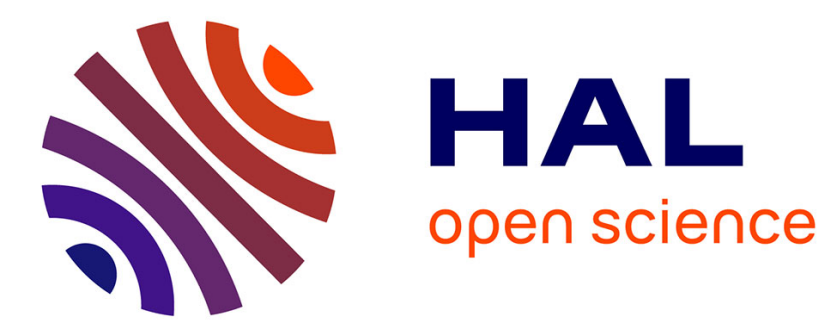

\title{
Commuting patterns in the metropolitan region of Rio de Janeiro. What differences between formal and informal jobs?
}

\author{
Benjamin Motte, Anne Aguilera, Olivier Bonin, Carlos D. Nassi
}

\section{To cite this version:}

Benjamin Motte, Anne Aguilera, Olivier Bonin, Carlos D. Nassi. Commuting patterns in the metropolitan region of Rio de Janeiro. What differences between formal and informal jobs?. Journal of Transport Geography, 2016, 51, pp.59- 69. 10.1016/j.jtrangeo.2015.10.019 . halshs-01374319

\section{HAL Id: halshs-01374319 \\ https://shs.hal.science/halshs-01374319}

Submitted on 24 Aug 2020

HAL is a multi-disciplinary open access archive for the deposit and dissemination of scientific research documents, whether they are published or not. The documents may come from teaching and research institutions in France or abroad, or from public or private research centers.
L'archive ouverte pluridisciplinaire HAL, est destinée au dépôt et à la diffusion de documents scientifiques de niveau recherche, publiés ou non, émanant des établissements d'enseignement et de recherche français ou étrangers, des laboratoires publics ou privés. 
Journal of Transport Geography, Volume 51, February 2016, Pages 59-69

Commuting patterns in the Metropolitan Region of Rio de Janeiro.

What differences between formal and informal jobs?

Benjamin Motte a,b, Anne Aguilera c, $*$, Olivier Bonin c, Carlos D. Nassi b

a Université de Bourgogne, THEMA, 2, bd Gabriel, F-21000 Dijon, France

b Transportation Engineering Program, Federal University of Rio de Janeiro, Bloco H-106, P.O. Box

68512, 21941-972 Rio de Janeiro, RJ, Brazil

c Université Paris-Est, IFSTTAR, LVMT, 14-20 boulevard Newton, Cite Descartes Champs sur Marne,

77447 Marne la Vallée Cedex 2, France

* Corresponding author. Tel.:+33 181668860 .

E-mail addresses: benjamin.motte@u-bourgogne.fr (B. Motte), anne.aguilera@ifsttar.fr (A. Aguilera), olivier.bonin@ifsttar.fr (O. Bonin), nassi@pet.coppe.ufrj.br (C.D. Nassi).

Article history:

Received 21 November 2014

Received in revised form 12 October 2015

Accepted 31 October 2015

\section{Keywords:}

Commuting

Informal jobs

Rio de Janeiro

\section{Abstract}

Limiting commuting trips in major cities is important from the environmental, social and economic standpoints. In order to design policies that aim to change commuting practices it is, however, necessary to have acquired a good understanding of the trips in question and their determinants. However, these trips have been subjected to very little study in the cities of developing countries. This paper is concerned with the Rio de Janeiro Metropolitan Area (RJMA), and sets out to test the influence of "classical" socioeconomic and spatial variables on the distance and duration of the commuting trips of the region's inhabitants, especially those with the lowest incomes.

The main original feature of this research is that it includes jobs in the informal sector. The results show that, all other things being equal, commuting distances and times are shorter for the informal sector, and people walk more from their homes to their place of work because jobs in the informal sector are more dispersed than jobs in the formal sectors. The notable exception is personal and household services for which employees (who are mainly women) live a long way from the city center where wealthy families (and their jobs) are concentrated. 


\section{Introduction}

Reducing commuting distances and duration in major cities is important from the environmental, social and economic standpoints (Givoni and Banister, 2013). The pressing need to reduce greenhouse gas emissions means we must greatly reduce the daily distances travelled by automobile. This can only be achieved by reducing the distance between residential locations and jobs and/or increasing the use of alternative modes of transport (Akerman and Hojer, 2006 ; Holden, 2012 ; Modarres, 2013). The social challenge is to ensure that the lowest income groups have access to jobs at costs which are acceptable not only in financial terms but also in terms of daily travel times (Lau, 2011 ; Lucas, 2011 ; MotteBaumwol and Nassi, 2012 ; Naudé, 2008; Yongling and Guonan, 2009). Last, the efficiency of commuting trips is a factor for firms' economic efficiency (Cervero, 2001), in particular because it reduces stress and fatigue among the workforce (Novaco and Gonzalez, 2009).

In order to design policies that aim to change commuting practices it is, however, necessary to have acquired a good understanding of the trips in question and their determinants. However, these trips have been subjected to less studies in the cities of developing countries (Garske et al., 2011; GuttierezPuigarnau and Van Ommeren, 2010; Punpuing, 1993; Salon and Gulyani, 2010; Shirgaokar, 2014). We have, in particular, only scant knowledge of the influence of the variables responsible for the differences between individuals in industrialized countries, for example income levels, gender, the type of job or residential location (Aguilera, 2005; Giuliano and Small, 1993; Shearmur, 2006).

This paper is concerned with the Rio de Janeiro Metropolitan Area (RJMA), and sets out to test the influence of "classical" socioeconomic and spatial variables on the distance and duration of the commuting trips of the region's inhabitants, especially those with the lowest incomes. In particular, we wish to test the hypothesis of a spatial mismatch (Kain 1968; Holzer 1991) between residential and work locations on the grounds that, in this Metropolitan region as in other Latin American cities cities, jobs are very highly concentrated in the Central Business District (CBD) and a few pericentral employment areas (Fernández-Maldonado et al. 2013). However, in recent decades the population, particularly the lowest income households, has moved out into the urban periphery (Rodríguez Vignoli 2008; Ribeiro and Lago 1995). Commuting distances have greatly increased, and commuting times even more so (Pereira and Schwanen 2013). Commuting times are higher for modest inhabitants of the municipalities of the north RMJA (Figure 2), highly dependent on employment centers from the municipality of Rio de Janeiro (CENTRAL 2005). .

Apart from the fact that it is concerned with a little-studied area, the main original feature of this research is that it includes jobs in the informal sector. This accounts for $55 \%$ of the jobs in Rio de Janeiro (Ramos and Ferreira 2006) and these jobs are mainly held by the individuals with the lowest incomes (Jonasson 2011; Bargain and Kwenda 2011). These jobs are more dispersed than formal sector jobs, which has the potential to mitigate any spatial mismatch. Moreover, the issue of the difference in terms of travel between formal and informal jobs has received little attention in the literature (Abane, 1993; Mitra, 2005). However, informal jobs have the potential to greatly reduce travel distances not only because the workers have to pay the entire cost of transport (which does not apply in the formal sector), but also because of the precarious nature and low remuneration of informal jobs (Bargain and Kwenda 2011). A. Abane (1993) showed that in Accra (Ghana) many informal workers, and particularly the female traders, prefer to live close to their business in order to reduce commuting costs but also because this is a way to ensure the safety of their wares. In India, A. Mitra (2005) highlighted that 
women in the unformal sector are constrained to choose a job close to their homeplace (which location is determined by their husband) firstly because of household responsibilities and secondly because they are can access jobs only to informal contacts in their neighbourhood.

This paper therefore sets out to identify the factors that influence the commuting distances and times among the residents of the Rio de Janeiro Metropolitan Area, distinguishing between formal and informal jobs. The first section consists of a literature review. The second presents the data we have used and describes the locations of the jobs and the residences of workers in the RJMA. Section three defines the informal jobs. The fourth section describes two linear regression models, one for commuting distance and the other for travel time. The findings are summarized in the conclusion. The results show that, all other things being equal, commuting distances and times are shorter for the informal sector, and people walk more from their homes to their place of work because jobs in the informal sector are more dispersed than jobs in the formal sectors. The notable exception is personal and household services for which employees (who are mainly women) live a long way from the city center where wealthy families (and their jobs) are concentrated.

\section{Literature review on the main factors affecting commuting distance and times}

The travel distance and travel time between an individual's residence and place of work vary according to his or her socioeconomic characteristics and according to the location of their residence and place of work (Charron, 2007; Dieleman et al., 2002; Giuliano and Small, 1993; Handy, 1996; Horner, 2002).

\subsection{Socioeconomic variables}

In industrialized countries, the wealthier individuals (who are also frequently the best qualified) tend to live further from their workplace than individuals on low incomes (Lee and McDonald, 2003; Plaut, 2006). The main reason for this is that wealthier individuals can afford to spend more on travel (Van Ommeren and Dargay, 2006): they have a higher automobile ownership rate and travel by automobile more often, and therefore at a higher average speed than lower income groups who are more dependent on public transport (Dargay and Hanly, 2007). Those with higher incomes can therefore choose a residential location which is a long way from their place of work, but this does not necessarily imply a longer travel time, and choose to live in municipalities which are socially uniform, with good shops, services, amenities and schools (Rouwendal and Meijer, 2001).

Whether individuals own or rent their home also influences their commuting practices: on average, home-owners live further from their jobs than individuals in rented accommodation (Lee and Mac Donald, 2003). This is because more home-owners live at some distance from the center in order to take advantage of lower prices (however, as we shall see, commuting distances increase with distance from the center), and on the other hand because moving costs may dissuade them from moving closer to their job.

Gender is also a differentiating factor: a large number of studies have shown that, on average, women live nearer to their work than their spouses, particularly in the case of two-worker households (Hjorthol and Vagane, 2014 ; Lee and McDonald, 2003 ; Sermons and Koppelman, 2001). This finding has 
recently been confirmed for two Brazilian cities - Sao Paolo and Belo Horizonte (De Miranda and Domingues, 2010; Neto et al., 2014). Spatial and temporal proximity to their work means women can have the time to look after their children and perform household tasks (Kwan, 2002; Turner and Niemeier, 1997). Another reason is that women are, on average, paid less than men, in particular because they more often work part-time (Manning and Petrongolo, 2008), and part-time workers, on average, live nearer their work in order to reduce the cost of travel from home to work (Hjorthol and Vagane, 2014 ; Maoh and Tang, 2012 ; Mercado and Paez, 2009).

Age is another influential factor. However, there is some disagreement in the literature regarding the nature of the link between age and commuting distance: some research concludes that there is a negative link (distance falls with age), while some more recent studies show exactly the opposite (Maoh and Tang, 2012). Other scholars take the view that the link between age and commuting distance is nonlinear, and linked to different stages in the life-cycle: the youngest and oldest workers tend to live nearer their job than workers aged between 35 and 45 years (Maoh and Tang, 2012 ; Morency et al., 2011).

Research into commuting journey times shows that these are influenced by the mode of transport used (Wang, 2001). As the speed is a higher for trips made by automobile, travel time is, on average, lower for workers who travel by automobile than for those who use public transport (Santos et al., 2013). However there does not seem to be any link between transport mode and commuting distance (Shearmur, 2006).

Finally, having a disability which reduces one's ability to travel limits the area within which it is possible to travel, and consequently commuting distances (Dejoux and Marin-Lamellet, 2010).

\subsection{Spatial variables}

Commuting times and distances vary according to the spatial position of the place of residence and the place of work within the metropolitan region. The further the home is from the center (CBD) or a peripheral employment area (in the case of a polycentric metropolitan area), the greater the commuting distance (Aguiléra, 2005; Wang, 2001). However, the journey time is not necessarily greater because of more systematic use of the automobile as it has been shown for instance in the San Francisco Bay Area (Cervero and Wu, 1997). In addition, a locally balanced worker-to-job ratio (or a situation where the number of jobs exceeds the number of economically active residents) is associated with lower commuting times and distances (Peng, 1997; Verhetsel and Vanelslander, 2010; Zhao et al., 2011). Lastly, on average, travel times and distances to jobs which are located within the CBD and the peripheral jobs areas are greater than to jobs located outside these areas because their better transport accessibility increases the size of their catchment area (Aguiléra, 2005).

\section{Data on job and residential locations in the RJMA}

2.1 Data on job locations and commuting in Brazil 
The sources of data for studying commuting journeys in Brazil are limited, in particular because the national census does not take all of them into account, even though there has been some progress in this area. Thus, the year 2000 census contains job locations and the 2010 census gives the duration of the commute. However, no information is given about the travel distance and mode. The PNAD survey, used by Pereira and Schwanen (2013) to study changes in commuting times between 1992 and 2009, also provides little information on the characteristics of the commuting journeys. It cannot therefore be used to analyze the factors that influence commuting times and distances.

This type of analysis is only possible on the basis of the origin-destination surveys conducted in large Brazilian cities. For this research we succeeded in accessing the 2003 Rio de Janeiro HTS which was conducted with appropriate variables and a sample size that was more than sufficient for the purposes of our analyses. Although it could be argued that this survey is dated, we feel that the findings are interesting and novel. Moreover, although the data from the 2012 Rio de Janeiro HTS should probably become available in 2015 after a number of delays, this survey is just an updated version of the 2003 survey with a much smaller sample. In view of the uncertainty this generates we chose to base our work on the 2003 HTS.

\subsection{Job locations and commuting journeys in the Rio de Janeiro 2003 HTS}

The Rio de Janeiro HTS was conducted between October 2002 and December 2003, on a sample of 34,000 households, containing 99,300 surveyed individuals who were each given a face-to-face interview in their home. The surveyed households were located throughout the RJMA, including in the favelas. The contents of the questionnaire were classical and provide information on the characteristics of the individuals, the household and its dwelling and finally all the trips each individual made the day before the survey day.

One third, i.e. slightly over 32,000 of the surveyed individuals were workers for whom we know the job and residential location as well as the characteristics of their commute. In Brazil, the employment rate is close to the OECD average (65.6\%), in particular because of the low participation in the labour market for some groups such as women (OECD, 2014). Moreover, the survey did not only consider adults, but included the children, even those aged under six years. This is not the case for many household surveys.

The residential and job location was given by an ad hoc division of the area covered into 485 zones which represent the smallest geographical level for the HTS data. Geographical sampling for the survey was conducted on the basis of this zoning, which we also used to compute road distances. For journeys that have origin and destination within the same zone, we computed half of the square root of the surface's area (Gascon et al., 2009). In order to represent the job locations, we aggregated the data at a higher nested level, that of the Administrative Regions in the case of Rio de Janeiro and the municicpios for the rest of the RJMA. The HTS zones have been aggregated for two reasons. First, the sampling of HTS didn't take into account the question of employment and workplaces. There are hundreds of zones without job or only a few dozen jobs, too few to estimate correctly the model including the sectors of activity and the formal and informal employment. Second, incorporating too many areas (and hence too many dummies) in a multivariate model would have led to increase 
artificially its explanatory capacity. That's why we have preferred the construction of geographically homogeneous areas.

Additionally, the trip durations were reported in the HTS. Last, in the case of individuals with several jobs, we took account of the characteristics of that which was reported as the principal job.

In order to evaluate the accuracy of the HTS with regard to the study of job locations, we compared the data it contains with that in the RAIS, a database which receives its data from the Brazilian Ministry of Labor. This database is Brazil's only comprehensive inventory of jobs. However, the information on job locations is imprecise and not always available at the sub-municipal level. In the case of Rio de Janeiro, joint work conducted by the Ministry of Labor and the local authorities has made it possible to generate this data at the scale of the administrative regions (Medeiros Junior 2011), which is the division we have used during this work.

A comparison between the figures 3 and 4 shows that the HTS provides a picture in which jobs are less concentrated in the main jobs area of the CBD. The other geographical areas have more jobs, but this does not affect the hierarchy between the zones and the general employment geography. The explanation for this lies in the sampling used for the HTS, which was done on the basis of individuals' place of residence and ignored their place of work. Once these limitations are recognized, we consider that the employment data in the HTS still serve our purposes, even if the lack of the possibility of making a comparison regarding the location of informal jobs introduces a degree of uncertainty.

Figure 1: Population densities in the Rio de Janeiro Metropolitan Area (RJMA)

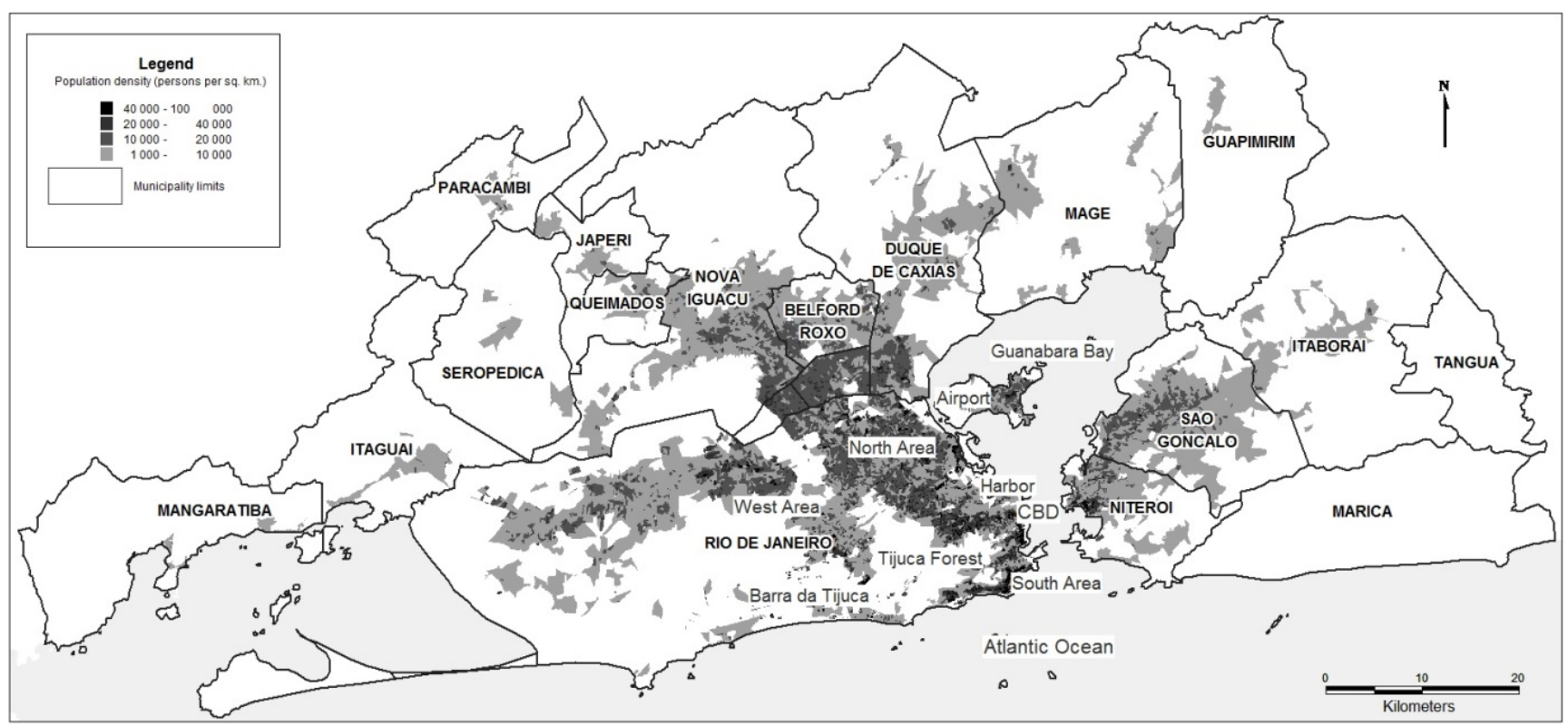

Source: Cartography by the authors from the National Population Census 2000 


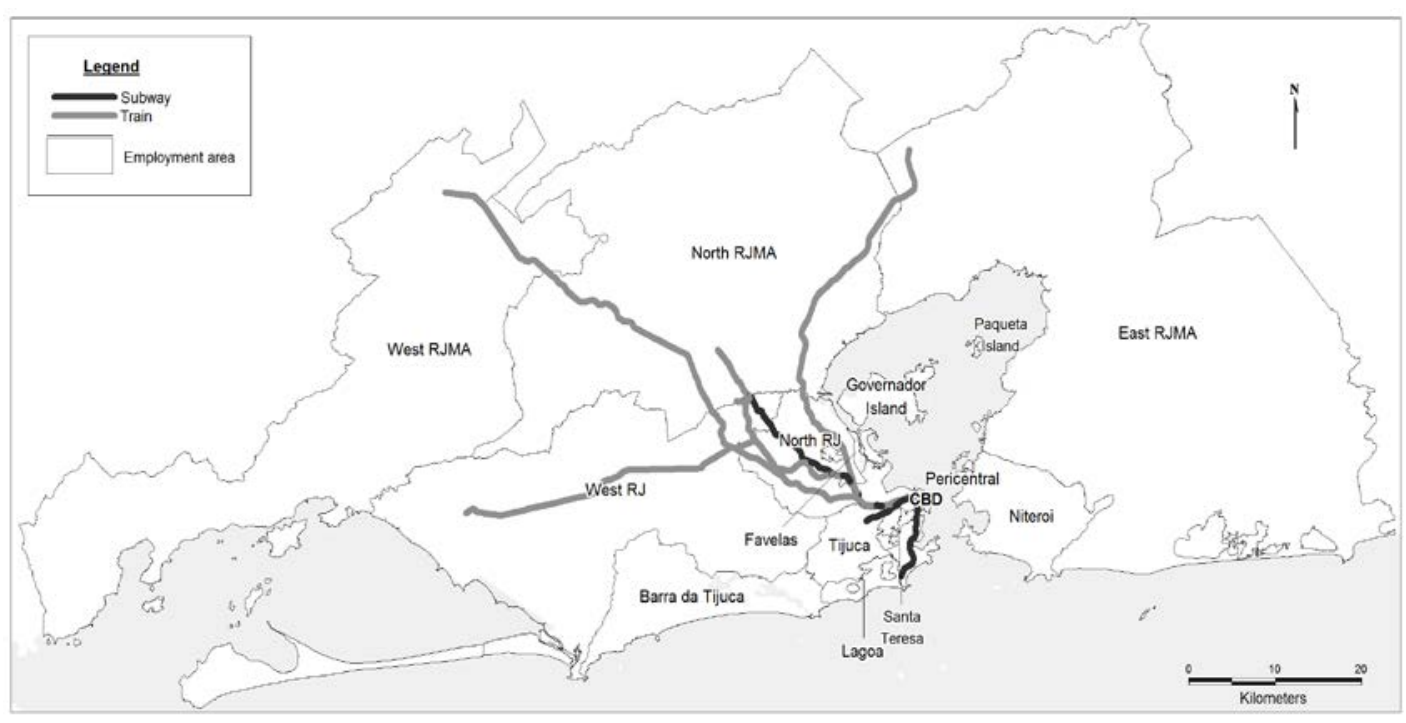

Source: Cartography by the authors

\subsection{A highly segregated population living in hilly terrain}

Before describing the employment geography, we shall provide some general information about the Rio de Janeiro Metropolitan Area. This RJMA had a population of 11.3 million in 2003, included 20 municipalities, and measured approximately $120 \mathrm{~km}$ from east to west and $50 \mathrm{~km}$ from north to south. The municipality of Rio de Janeiro, which was both the largest and the most populated, contained $53.8 \%$ of the population. The population geography of the Rio de Janeiro is affected by its coastal position, along Guanabara bay in the case of the North Area (a coastal plain) and facing the Atlantic Ocean, along the beaches. Settlement has also had to fit in with the hilly topography. The city has been built in a landscape of hills and valleys, and settlement is very low, or even non-existent, on the steepest hills. The outcome is areas with very low population densities, even only a few kilometers from the CBD. The city also contains the Parque Nacional da Tijuca, a national park with one of the world's largest urban forests.

The population of Rio de Janeiro is highly segregated with a poor, sometimes very poor, northern zone and a rich, sometimes very rich, southern zone. The wealthiest people live along the Atlantic coast, and have moved further and further from the center as the city has expanded. The many favelas squeezed onto the hillsides overlooking the wealthy districts have a poor population. However, although there are a large number of favelas, they contain only a small proportion of the poorest inhabitants, most of whom live along the polluted edges of Guanabara Bay, and on the coastal plain that begins there (IBGE, 2013). The middle classes, which were a small part of Brazilian society in 2003, tend to live in the areas between the north and the south of the city.

\subsection{Jobs are concentrated in the center of the RJMA}

Rio de Janeiro's CDB accounts for $28 \%$ of the jobs in the metropolis. Adjacent to it are three smaller employment areas, Harbor and South Area and, on the other side of Guanabara Bay, Niteroi. 
Together, these account for slightly over $20 \%$ of the jobs. Half the region's jobs are therefore concentrated in four areas that are located close together in the center of the RJMA. Although these areas are close to each other they are characterized by different sectors of activity.

Figure 3: Formal jobs (source RAIS)

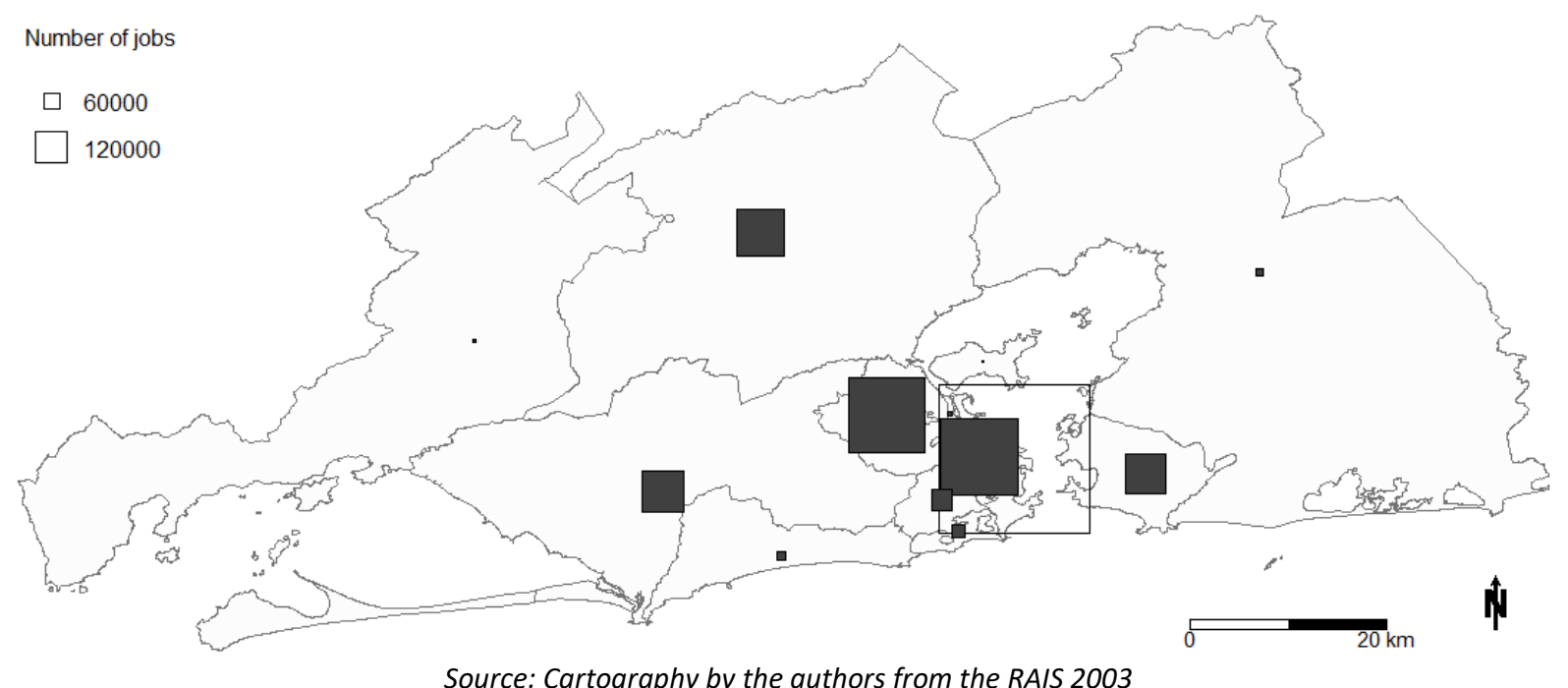

Figure 4: Formal jobs (source HTS)

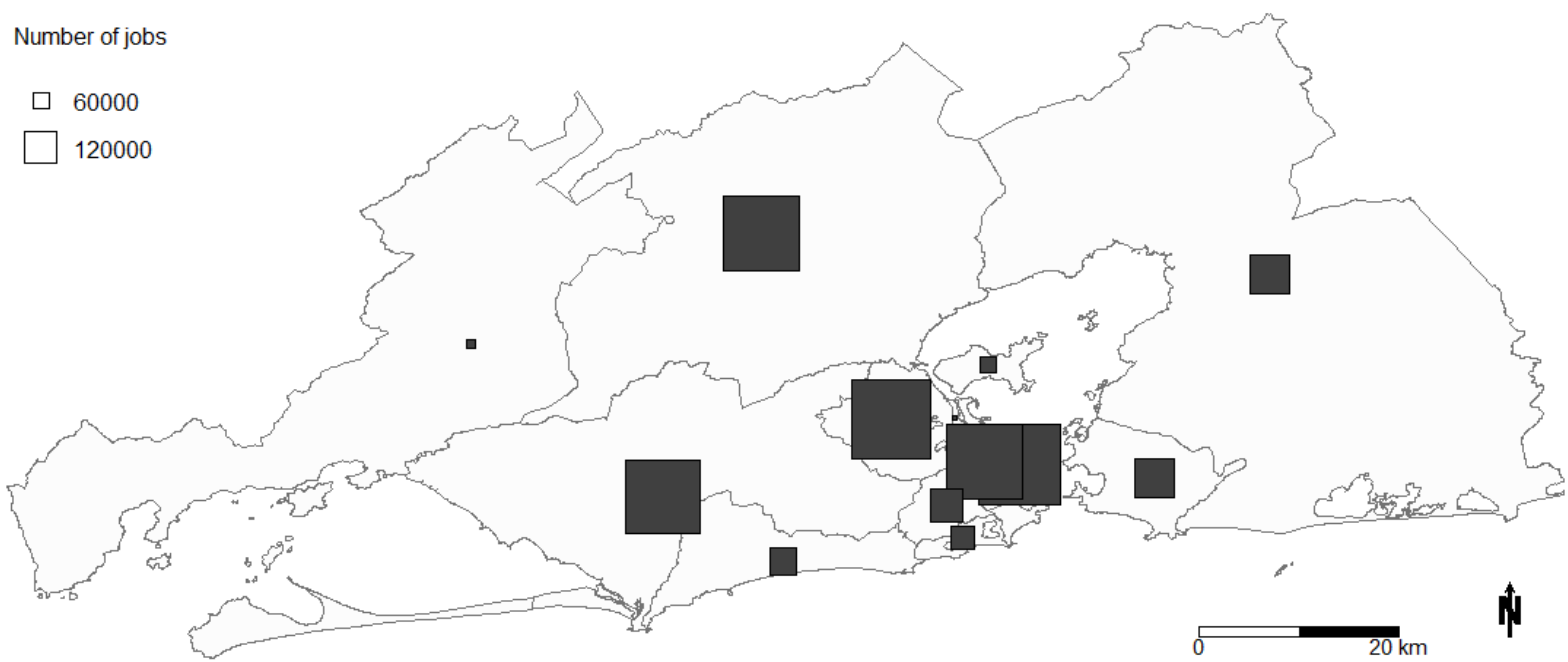

Source: Cartography by the authors from the Rio de Janeiro HTS 2003

- The CBD has by a high proportion of service sector jobs, particularly public and expert services, which together account for almost $58 \%$ of its jobs. Also, quite a large proportion of the jobs, almost $20 \%$, are in shops, but this figure is nevertheless below the average for the Metropolitan area as a whole which stands at $24 \%$. The CBD is also characterized by the strong presence of jobs in banking and finance, which account for more than $6 \%$ of the jobs compared with barely more than $1 \%$ within the metropolis as a whole.

- The RJMA's second jobs area is located to the north west of the CBD, and takes in a large part of the port and the areas of Sao Cristovao and Ramos. It is characterized by a high proportion of industrial jobs and jobs in the trunk freight transport sector, due to the presence of the port. Together, these account for almost $20 \%$ of this area's jobs, compared with $11 \%$ on average in 
the rest of the RJMA. Expert services are also well represented in this employment area.

- The third employment area is located in the southern part of the municipalities of Rio de Janeiro. It is characterized by a high proportion of service jobs: expert services and domestic services, but not public services. The reason for this is that the people who live in this employment area have a high level of income which explains its higher proportion of jobs in domestic services and services in general. This employment area also has a large number of jobs in tourism because the large number of hotels, particularly in the Copacabana district.

- The Niteroi employment area has no specific characteristics apart from the high presence of public service jobs and the small number of retail jobs. In fact, Niteroi is not an employment area at the Metropolitan level, it is more the employment area for the south-eastern part of Guanabara Bay.

\section{Definition and location of informal jobs}

\subsection{Informal jobs in the HTS}

Informal jobs are defined by the International Labor Organization (ILO) on the basis of the type of production unit (firms in the formal sector, firms in the informal sector or households) and the status of the job (own-account workers, employees, contributing family workers ...). According to this definition, formal jobs (formal jobs in the formal sector) only accounted for $40.6 \%$ of all jobs in Brazil in 2003 , compared with the figure of $59.5 \%$ for informal jobs which is made up of $22.6 \%$ of informal sector employees and $36.8 \%$ of own-account workers (Hallak Neto, Namir, and Kozovits 2012). These figures vary according to the Metropolitan regions considered. The percentage of informal jobs in the municipalities of Rio de Janeiro was approximately 55\% in 2002 (Ramos and Ferreira 2006).

The HTS does not provide the same amount of detail about informal jobs as it gives no information about the type of production unit. The only information we have about informal work is job status. Consequently, the results of the Rio de Janeiro HTS are not at all comparable with those in the national statistics. In the HTS formal jobs account for $59.3 \%$ of the workforce, the informal sector accounts for $18.2 \%$ and the self-employed $16.3 \%$. However, a great many of the informal jobs mentioned in the national statistics involve families who produce for their own consumption. It is probable that in the HTS, the individuals belong to such households have not described themselves as working in the informal sector or as self-employed. If we remove these individuals from the national statistics we obtained figures of $51.6 \%, 20.1 \%$ and $28.3 \%$ respectively (Hallak Neto, Namir, and Kozovits 2012), which are fairly close to the results obtained from the HTS. We should nevertheless bear in mind that informal jobs are probably underrepresented in the Rio de Janeiro HTS.

Based on the HTS, the gender mix in the informal sector is much the same as in the formal sector. Individuals with an informal job tend to be older with a lower level of educational attainment. These preliminary results concur with those from some other sources (Henley, Arabsheibani, and Carneiro 2009). In addition, informal work is present to different degrees in different sectors of activity. Twothirds of the jobs in building and public works are informal compared with slightly more than a third in 
retail and only $16.5 \%$ in industry. In terms of numbers, it is however retail which has the largest number of informal jobs (32.1\% of all informal jobs), followed by services (22.3\%), personal and household services (11.9\%), building and public works (8.5\%) and, last, expert services (8.4\%). These results for different sectors are consistent with those obtained by Ramos (2002) and Ramos and Ferreira (2006) using data from the Monthly Employment Survey (Pesquisa Mensal de Emprego - IBGE).

\subsection{The scattered nature of informal jobs}

Unlike formal jobs, informal jobs are not concentrated in the CBD. The spatial distribution of informal jobs is more dispersed (Theil index of 0.34 and Moran's I of 0.12 from the 485 zones of the HTS) than that observed for formal jobs (Theil index of 0.58 and Moran's I of 0.22). More generally, no high concentration of informal jobs is apparent in of the any zones in the RJMA. The location quotients nevertheless show that most informal jobs are in the main favelas of the municipality of Rio de Janeiro followed by the peripheral zones of the RJMA. Conversely, there are few informal jobs in the major employment areas for formal jobs and, generally, in the wealthy districts of the southern zone. The only exception to this pattern is informal jobs in the personal and household services sector because a substantial proportion of these jobs are located in the wealthy districts of the southern zone due to demand for personal and household services.

Figure 5: Informal jobs

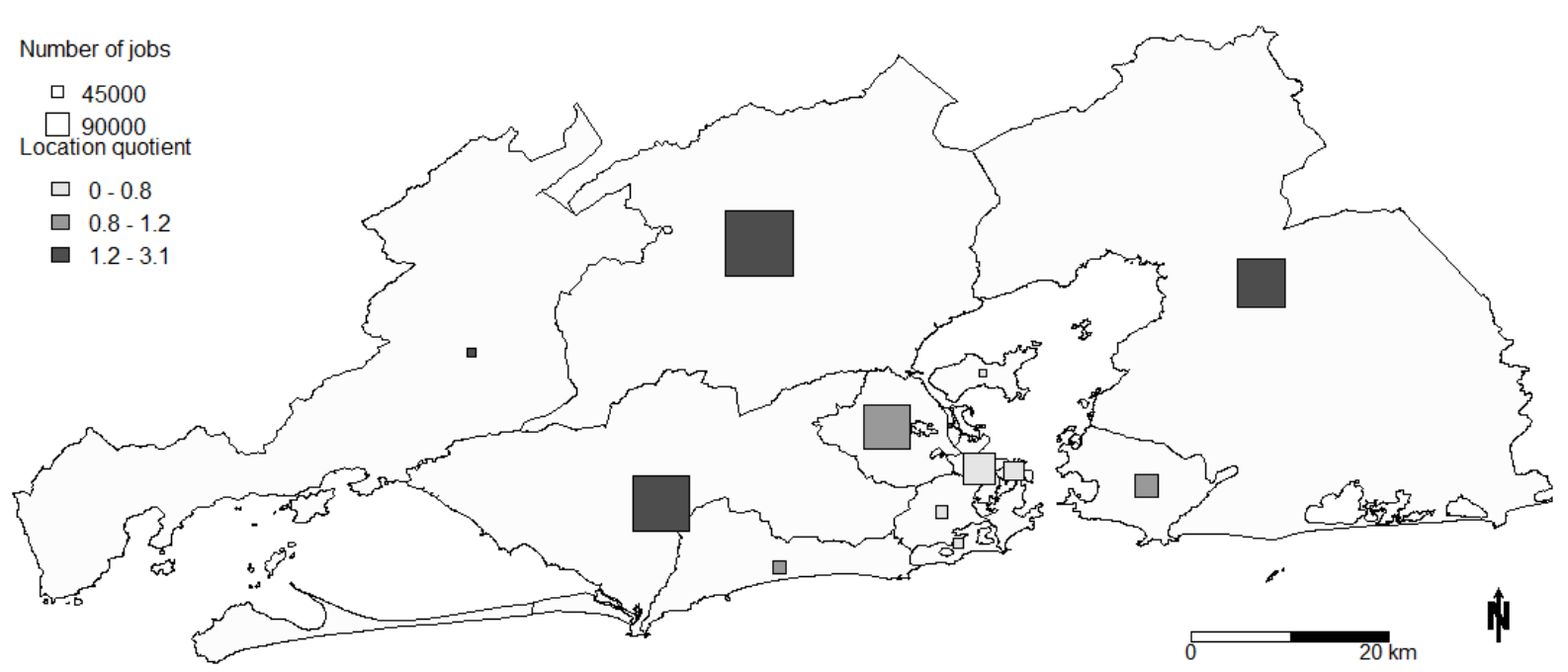

Source: Cartography by the authors from the Rio de Janeiro HTS 2003 
Figure 6: Residential location of individuals with an informal job

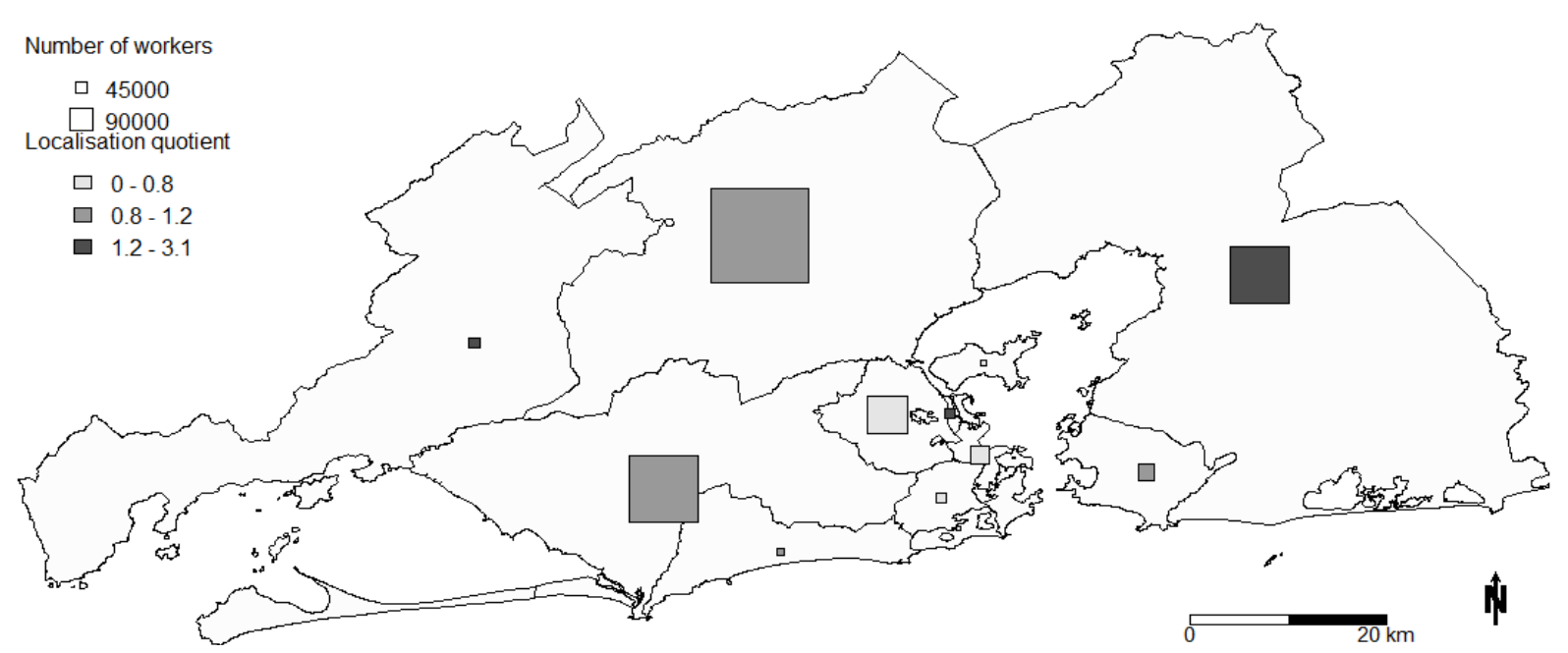

Source: Cartography by the authors from the Rio de Janeiro HTS 2003

Workers with an informal job tend to live in areas and municipalities that are peripheral to the main concentrations of jobs. They are also more highly represented in low income areas. Individuals with informal jobs are therefore overrepresented in the favelas of Rio de Janeiro.

\section{Commuting trips}

This part of the paper is based on a structural equation model (SEM) with four regressions: distance from home to work, duration of the commute, probability to commute by car and probability to commute by public transport. The explanatory variables relate to the determinants we have mentioned in the literature review, conditional on their availability in the database we used. The variables in question are described in Table 1 and explained below.

The framework of SEM is an extension of several statistical techniques, among which the simultaneous equation models, which is why this approach has been chosen here. It enables to estimate several regressions in one pass, and to take into account correlations between dependent variables, being thus a generalization of two-stage least squares. The possibility to include latent variables in SEM has not been used here: we only use simultaneous equations, as well as the possibility for a variable to be exogenous in one equation and endogenous in another one at the same time.

The model has been estimated with the help of the lavaan.survey package from the R software. This package is an extension from the lavaan package (Rosseel, 2012) that enables to take into account sampling weights in the models.

\subsection{The explanatory (exogenous) variables}

The first series of explanatory variables describes the socioeconomic characteristics of the individuals (gender, positioning the family, age, position in the household and level of educational attainment) and their job (an 18 modality variable describes the sector of activity and whether the job in question belongs to the formal or the informal sector). Two variables, namely the level of educational 
attainment and the type of job, are used as proxies for the individual's income which was not provided by the survey. Last, the variable states whether the individual suffers from a disability that is likely to impair his or her mobility.

A second series of variables relates to the type of job and the place of work. A variable which combine the sector of activity and formal/informal employment is used in the regressions. The combination of these two variables has two objectives. The first is to test the hypothesis that the characteristics of commuting are not homogeneous for all informal jobs and are differentiated by sectors of activity. The second objective is to avoid autocorrelation because in several sectors (FIRE and public services) informal employment are very little represented. The location of the job takes account of its distance from the $\mathrm{CBD}$ and the 14 zones identified in the previous section. The location has many impacts in Rio de Janeiro, for example whether it is located on an island, in Guanabara Bay, in the Forest of Tijuca or in a hilly area. As a consequence, many areas have highly specific characteristics as regards the accessibility of jobs which are not apparent just from straight line distances to the CDB.

Last, we consider the mode of transport used for the commute (car and public transport) as an explanatory variable of the duration of the journey, in accordance with what we explained in the first section, as well as a dependent variable, to overcome the problem of omitted variables that might be correlated to both variables, as job choice.

The results of the model are shown in Table 2 . The model validates the hypothesis that there are differences between formal and informal jobs. However, the observed differences relate more to distances than journey times. Table 3 shows the correlation between the dependent variables of the model. The correlation between commuting time and commuting distance is strong as expected. Commuting by car is faster and enables to go farther.

Table 1: The variables used in the models

\begin{tabular}{|c|c|c|c|c|}
\hline Variable & Modality & Formal & Informal & Together \\
\hline \multicolumn{2}{|c|}{ Mean commuting distance (kilometers) } & 10.6 & 6.4 & 9.0 \\
\hline \multicolumn{2}{|c|}{ Mean commuting time (minutes) } & 47.9 & 38.3 & 44.9 \\
\hline \multirow{7}{*}{$\begin{array}{l}\text { Gender and position in } \\
\text { household }\end{array}$} & Male Household Head & 43.1 & 44.3 & 43.6 \\
\hline & Female Household Head & 9.3 & 11.6 & 10.1 \\
\hline & Female spouse & 15.0 & 17.7 & 16.0 \\
\hline & Son of household head & 14.0 & 12.5 & 13.4 \\
\hline & Daughter of household head & 12.0 & 7.7 & 10.4 \\
\hline & Other male & 3.1 & 3.6 & 3.3 \\
\hline & Other female & 3.5 & 2.6 & 3.2 \\
\hline \multirow[t]{4}{*}{ Educational attainment } & Primary & 35.4 & 55.3 & 43.0 \\
\hline & High School & 40.0 & 33.3 & 37.4 \\
\hline & Some University & 6.0 & 3.2 & 4.9 \\
\hline & Graduate and postgraduate & 18.6 & 8.2 & 14.6 \\
\hline \multirow[t]{9}{*}{ Sector of activity } & Agriculture & 0.7 & 1.6 & 1.0 \\
\hline & Construction & 2.7 & 8.5 & 4.9 \\
\hline & Industry & 7.9 & 2.8 & 6.0 \\
\hline & Retail & 24.1 & 32.1 & 27.2 \\
\hline & Transport & 5.3 & 5.4 & 5.3 \\
\hline & Fire & 2.1 & 0.6 & 1.5 \\
\hline & Medical & 7.7 & 3.0 & 5.9 \\
\hline & Education & 7.5 & 2.7 & 5.7 \\
\hline & Services & 15.9 & 22.3 & 18.4 \\
\hline
\end{tabular}




\begin{tabular}{llrrr} 
& Services publics & 10.5 & 0.7 & 6.7 \\
& Expert services & 10.7 & 8.4 & 9.8 \\
& Personal and household services & 5.0 & 11.9 & 7.6 \\
\hline Place of work & CBD & 13.1 & 9.2 & 11.6 \\
& Pericentral & 14.1 & 5.5 & 10.8 \\
& Lagoa & 4.1 & 2.9 & 3.6 \\
& Tijuca & 5.7 & 3.6 & 4.9 \\
& North RJ & 13.6 & 13.0 & 13.4 \\
& West RJ & 12.9 & 16.1 & 14.2 \\
& Governor Island & 2.9 & 2.0 & 2.5 \\
& Paqueta Island & 0.0 & 0.0 & 0.0 \\
& Santa Teresa & 0.2 & 0.4 & 0.3 \\
& Barra da Tijuca & 4.6 & 3.8 & 4.3 \\
& Favelas & 0.6 & 1.3 & 0.9 \\
& North RJMA & 13.2 & 19.1 & 15.4 \\
& Niteroi RJMA & 6.8 & 6.7 & 6.8 \\
& East RJMA & 6.6 & 13.8 & 9.3 \\
& West RJMA & 1.5 & 2.6 & 1.9 \\
\hline Transport mode & Other & 0.7 & 1.2 & 0.9 \\
& Walk & 11.3 & 23.2 & 15.0 \\
& Motorized two-wheeler & 3.3 & 6.8 & 4.4 \\
& Automobile & 14.7 & 15.5 & 15.0 \\
& Public transport & 70.0 & 53.3 & 64.8 \\
\hline
\end{tabular}

Source: Calculated by the authors from the Rio de Janeiro HTS 2003

Table 2: Commuting time/distance model

\begin{tabular}{|c|c|c|c|c|}
\hline Variable & Modality & Estimate & Std.err & $P(>|z|)$ \\
\hline \multicolumn{5}{|c|}{ COMMUTING TIME } \\
\hline \multicolumn{2}{|c|}{ Transport mode automobile } & -6.250 & 0.704 & 0.000 \\
\hline \multirow{17}{*}{$\begin{array}{l}\text { Sector of } \\
\text { activity and } \\
\text { type of job } \\
\text { (ref : } \\
\text { education) }\end{array}$} & Agriculture & -0.998 & 2.998 & 0.739 \\
\hline & Formal construction & 9.089 & 2.220 & 0.000 \\
\hline & Inf. construction & 2.773 & 2.224 & 0.212 \\
\hline & Formal industry & 10.430 & 1.496 & 0.000 \\
\hline & Inf. industry & 10.411 & 3.072 & 0.001 \\
\hline & Formal retail & 3.011 & 1.199 & 0.012 \\
\hline & Inf. retail & -1.419 & 1.797 & 0.430 \\
\hline & Transport & 3.354 & 1.639 & 0.041 \\
\hline & Fire & 7.092 & 2.282 & 0.002 \\
\hline & Medical & 5.490 & 1.371 & 0.000 \\
\hline & Formal services & 8.333 & 1.411 & 0.000 \\
\hline & Inf. services & 1.953 & 1.918 & 0.309 \\
\hline & Public services & 7.338 & 1.417 & 0.000 \\
\hline & Formal expert services & 7.693 & 1.416 & 0.000 \\
\hline & Inf. expert services & 2.521 & 2.330 & 0.279 \\
\hline & Formal pers. \& househ. services & 4.515 & 1.967 & 0.022 \\
\hline & Inf. pers. \& househ. services & 6.697 & 2.334 & 0.004 \\
\hline \multicolumn{2}{|c|}{ Informal job (dummy) } & -3.153 & 1.445 & 0.029 \\
\hline \multicolumn{2}{|c|}{ Distance to CBD (km.) } & -0.140 & 0.029 & 0.000 \\
\hline \multirow{2}{*}{$\begin{array}{l}\text { Place of work } \\
\text { (ref: CBD) }\end{array}$} & Pericentral & -10.463 & 1.223 & 0.000 \\
\hline & Lagoa & -13.173 & 1.848 & 0.000 \\
\hline
\end{tabular}




\begin{tabular}{|c|c|c|c|c|}
\hline & Tijuca & -15.258 & 1.550 & 0.000 \\
\hline & North RJ & -16.179 & 1.185 & 0.000 \\
\hline & West RJ & -18.989 & 1.550 & 0.000 \\
\hline & Governor Island & -22.086 & 2.082 & 0.000 \\
\hline & Paqueta Island & -46.442 & 4.210 & 0.000 \\
\hline & Santa Teresa & -25.713 & 4.816 & 0.000 \\
\hline & Barra da Tijuca & -3.405 & 1.876 & 0.069 \\
\hline & Favelas & -30.535 & 3.342 & 0.000 \\
\hline & North RJMA & -22.834 & 1.458 & 0.000 \\
\hline & Niteroi RJMA & -19.705 & 1.355 & 0.000 \\
\hline & East RJMA & -29.339 & 1.693 & 0.000 \\
\hline & West RJMA & -22.136 & 2.962 & 0.000 \\
\hline \multirow{6}{*}{$\begin{array}{l}\text { Position in } \\
\text { household } \\
\text { (ref: Male } \\
\text { household } \\
\text { head) }\end{array}$} & Female household head & -1.973 & 1.012 & 0.051 \\
\hline & Female spouse & -5.687 & 0.781 & 0.000 \\
\hline & Son of household head & -0.582 & 0.830 & 0.483 \\
\hline & Daughter of household head & -0.415 & 0.887 & 0.640 \\
\hline & Other male & -3.774 & 1.655 & 0.023 \\
\hline & Other female & -4.870 & 1.480 & 0.001 \\
\hline \multirow{3}{*}{$\begin{array}{l}\text { Educational } \\
\text { attainment } \\
\text { (ref: Primary) }\end{array}$} & High School & 8.451 & 0.926 & 0.000 \\
\hline & Some University & 7.940 & 0.808 & 0.000 \\
\hline & Graduate and postgraduate & 4.958 & 1.222 & 0.000 \\
\hline \multicolumn{5}{|c|}{ COMMUTING DISTANCE } \\
\hline \multicolumn{2}{|c|}{ Transport mode automobile } & 3.436 & 0.318 & 0.000 \\
\hline \multirow{17}{*}{$\begin{array}{l}\text { Sector of } \\
\text { activity and } \\
\text { type of job } \\
\text { (ref : } \\
\text { education) }\end{array}$} & Agriculture & -0.487 & 1.119 & 0.664 \\
\hline & Formal construction & 2.888 & 0.969 & 0.003 \\
\hline & Inf. construction & 1.683 & 0.788 & 0.033 \\
\hline & Formal industry & 4.116 & 0.585 & 0.000 \\
\hline & Inf. industry & 5.521 & 1.323 & 0.000 \\
\hline & Formal retail & 0.030 & 0.432 & 0.944 \\
\hline & Inf. retail & 0.328 & 0.636 & 0.605 \\
\hline & Transport & 1.436 & 0.580 & 0.013 \\
\hline & Fire & 1.796 & 0.945 & 0.057 \\
\hline & Medical & 2.238 & 0.571 & 0.000 \\
\hline & Formal services & 2.981 & 0.555 & 0.000 \\
\hline & Inf. services & 2.191 & 0.726 & 0.003 \\
\hline & Public services & 2.584 & 0.596 & 0.000 \\
\hline & Formal expert services & 1.736 & 0.574 & 0.002 \\
\hline & Inf. expert services & 0.676 & 0.878 & 0.442 \\
\hline & Formal pers. \& househ. services & 0.998 & 0.797 & 0.210 \\
\hline & Inf. pers. \& househ. services & 3.944 & 0.840 & 0.000 \\
\hline \multicolumn{2}{|c|}{ Informal job (dummy) } & -2.205 & 0.531 & 0.000 \\
\hline \multicolumn{2}{|c|}{ Distance to CBD (km.) } & 0.031 & 0.011 & 0.006 \\
\hline \multirow{4}{*}{$\begin{array}{l}\text { Place of work } \\
\text { (ref: CBD) }\end{array}$} & Pericentral & -7.841 & 0.593 & 0.000 \\
\hline & Lagoa & -10.736 & 0.843 & 0.000 \\
\hline & Tijuca & -12.435 & 0.695 & 0.000 \\
\hline & North RJ & -13.611 & 0.560 & 0.000 \\
\hline
\end{tabular}




\begin{tabular}{|c|c|c|c|c|}
\hline & West RJ & -15.587 & 0.659 & 0.000 \\
\hline & Governor Island & -14.051 & 0.784 & 0.000 \\
\hline & Paqueta Island & -21.145 & 1.966 & 0.000 \\
\hline & Santa Teresa & -10.501 & 3.875 & 0.007 \\
\hline & Barra da Tijuca & -5.396 & 0.825 & 0.000 \\
\hline & Favelas & -18.859 & 0.940 & 0.000 \\
\hline & North RJMA & -16.614 & 0.649 & 0.000 \\
\hline & Niteroi RJMA & -12.576 & 0.665 & 0.000 \\
\hline & East RJMA & -17.794 & 0.692 & 0.000 \\
\hline & West RJMA & -15.795 & 1.237 & 0.000 \\
\hline \multirow{6}{*}{$\begin{array}{l}\text { Position in } \\
\text { household } \\
\text { (ref: Male } \\
\text { household } \\
\text { head) }\end{array}$} & Female household head & -2.809 & 0.408 & 0.000 \\
\hline & Female spouse & -2.973 & 0.324 & 0.000 \\
\hline & Son of household head & -0.125 & 0.346 & 0.717 \\
\hline & Daughter of household head & -1.356 & 0.373 & 0.000 \\
\hline & Other male & -1.357 & 0.714 & 0.057 \\
\hline & Other female & -2.974 & 0.610 & 0.000 \\
\hline \multirow{3}{*}{$\begin{array}{l}\text { Educational } \\
\text { attainment } \\
\text { (ref: Primary) }\end{array}$} & High School & 4.048 & 0.407 & 0.000 \\
\hline & Some University & 4.346 & 0.369 & 0.000 \\
\hline & Graduate and postgraduate & 3.077 & 0.541 & 0.000 \\
\hline \multicolumn{5}{|c|}{ TRANSPORT MODE: AUTOMOBILE } \\
\hline \multirow{6}{*}{$\begin{array}{l}\text { Position in } \\
\text { household } \\
\text { (ref: Male } \\
\text { household } \\
\text { head) }\end{array}$} & Female household head & -0.128 & 0.011 & 0.000 \\
\hline & Female spouse & -0.105 & 0.009 & 0.000 \\
\hline & Son of household head & -0.102 & 0.010 & 0.000 \\
\hline & Daughter of household head & -0.193 & 0.010 & 0.000 \\
\hline & Other male & -0.101 & 0.017 & 0.000 \\
\hline & Other female & -0.168 & 0.015 & 0.000 \\
\hline \multirow{3}{*}{$\begin{array}{l}\text { Educational } \\
\text { attainment } \\
\text { (ref: Primary) }\end{array}$} & High School & -0.385 & 0.011 & 0.000 \\
\hline & Some University & -0.274 & 0.012 & 0.000 \\
\hline & Graduate and postgraduate & -0.163 & 0.019 & 0.000 \\
\hline \multicolumn{2}{|c|}{ Informal job (dummy) } & 0.050 & 0.007 & 0.000 \\
\hline
\end{tabular}

\subsection{Influence of socioeconomic variables}

As in many other metropolises in different parts of the world, women's commuting trips are shorter than men's, both in distance and time. Neto et al. (2014), working in Sao Paolo, consider that the household responsibility hypothesis seems to be part of the reason for women's shorter commutes, but there are probably also specific cultural and environmental factors reflecting attitudes about gender in Brazil, whereby men tend to be socially dominant (DeSouza et al., 2004). Thus, the duration of women's commutes is even shorter when they live as part of a couple than when they are the household head. More generally, individuals who are not the chief earner in their household have shorter commutes, both in time and distance, irrespective of whether they are male or female.

In contrast to many studies that deal with developed countries in North America and Europe, in the RJMA the level of education has a negative effect on commuting times and distances. Those with the 
highest qualifications are those with the shortest commuting times and distances. Individuals who are educated live nearer to their work, both in terms of distance and ime. These findings differ from those obtained in the Sidney metropolitan area (Watts, 2009) but are similar to those obtained in Colombus, Ohio (Wang, 2001). The results obtained in Rio de Janeiro are explained by the very high degree of socio-spatial segregation that exists in the metropolitan area, and the fact that the geography of wealthy social groups and educated jobs coincides to a very high degree. In North American and European cities, urban forms are different, with a high proportion of the wealthy households living far from the center.

\subsection{Influence sector of activity and job status (formal/informal)}

The SEM model validates the hypothesis that there are differences between formal and informal jobs. Commuting times and distances are lower for informal jobs. The reason for this is twofold. First, informal jobs are more scattered than formal jobs, which makes it easier to find a match between place of work and place of residence. Second, as the employer makes no contribution towards the cost of transport in the case of an informal job, and as salaries also tend to be lower, people tend to look for work near their home. However there are differences between sectors of activity for which statistics are available for both formal and informal jobs. For construction, services and expert services commuting times and distances for informal jobs are lower than for formal jobs. But, for retail and industry there are no significant differences between informal and formal employment. It might be because informal and formal jobs in retail and industry are located in the same facilities in the same locations. Industry is the sector with the longest commuting times and distances probably because some facilities are located in sparsely populated peripheral areas. Finally for personal and household services, commuting times and distances are longer for informal jobs. The workers in this sector (who are mainly women) live a long way from the city center where wealthy families (and therefore jobs in this sector) are concentrated.

\subsection{Influence of place of work}

Our research also confirms the influence of spatial variables (distance between the place of work and the CBD and type of employment area), for which most of the modalities are significant. The distance from the CBD highlights the fact that centrally-located jobs require the longest commutes, as is the case in the metropolises of Europe and North America (Aguiléra, 2005; Shearmur, 2006). Conversely, commuting journeys become shorter the further the place of work is from the CBD, particularly in the case of those located in the most peripheral and/or least accessible areas of West RJ, West RJMA, Paqueta Island, North RJMA and East RJMA. Thus, the commuting distance is lower for the jobs that are located in all the other employment areas in the RJMA than for those located in the CBD.

Two peripheral employment areas are nevertheless marked out by commuting distances that are considerably longer than their neighbors. These are Governor Island, which includes the employment area of the international airport. This is because of the attractive nature of the jobs which are located there, but also the employment area's insular location. The second area is Barra da Tijuca which is a recently built area on the outskirts of the metropolis with a large number of residential districts 
occupied by the wealthy. It has much more marked activity zoning, leading to increased automobile use among its residents, while the socio-spatial segregation is highly pronounced, making it impossible for poor workers providing personal and household services to live near their place of work.

The opposite situation applies in two employment areas, where commuting distances are lower than in their neighbors. The first contains the jobs which are located in Rio de Janeiro's principal favelas where commuting distances are among the shortest. These jobs are therefore mostly held by individuals who live in the favelas in question and do not attract workers from outside. The second is the Niteroi area which is characterized by relatively short commuting distances even though it is one of the RJMA's main employment areas. But because it is on the other side of the bay, the poor quality of the links between the two sides of the bay means that Niteroi remains a local employment area and does not draw in workers from the east of the RJMA.

\section{Discussion - Conclusion}

In the RJMA, jobs are concentrated in the CBD and the secondary employment areas that are adjacent to it. The longest commutes are into the center and the journeys made by individuals living in the outskirts. This situation is not unique, but it is particularly marked in an monocentric region like the RJMA. However, unlike the situation in Europe and North America, it is not the individuals with the highest qualifications who have the longest commuting journeys. As in many South American cities, a high proportion of highly qualified workers live in central districts which are not far from the CBD. In particular, in Rio de Janeiro, the wealthiest groups have settled along the Atlantic coast. In addition, many members of the professions have their place of work in the district where they live. This tends to limit the length of the commutes made by highly qualified workers. This applies particularly to doctors and lawyers who are overrepresented in the districts along the coast.

The existence of a spatial mismatch means that the poorest groups and those with the least qualifications have the longest and most arduous commuting journeys, which are usually on buses that are uncomfortable, packed and rarely air conditioned. However, informal jobs allow us to qualify this observation. Informal jobs are much more dispersed with shorter commuting journeys. More precisely, it is informal jobs in retail and the expert services that have the shortest commutes. There is, however, one exception - household services. In the case of these jobs, which are mainly done by women, the high degree of sociospatial segregation between the locations of jobs and the places of residence of the workers leads to substantial distances between workers and employers, in both the formal and informal sectors. Moreover, more individuals with an informal job in the personal and household services sector walk to work ( $30 \%$ go to work by foot against $16 \%$ in the formal sector according to the $2003 \mathrm{HTS}$ ) as, unlike people working in the formal sector, they do not receive any help with their travel expenses. In some cases this means they have to walk great distances leading to commuting times that are very much longer than those of other workers.

Commuting patterns have received less attention in developing countries whereas the environmental, social and economical challenges are very important. Research is needed in this field and must absolutely take into account not only formal but also informal jobs. The results we obtained in this 
paper provided interesting results but they are only valid for Rio de Janeiro. Hence further studies are needed to make comparisons with other Brazilian Cities for which comparable data are available. Last, in Brazil and then in Rio de Janeiro there has been an important increase in motorization rate (Rodrigues, 2013) as well as a growth of the formal employment (Ineri, 2011). More recent data would enable to determine if these factors have an impact on the differences between formal and informal jobs.

\section{References}

Åkerman, J., Höjer, M., 2006. How much transport can the climate stand?-Sweden on a sustainable path in 2050. Energy policy 34(14), 1944-1957.

Abane, A., 1993. Mode choice for the journey to work among formal sector employees in Accra, Ghana. Journal of transport geography 1(4), 219-229.

Bargain, O., Kwenda, P., 2011. Earnings Structures, Informal Employment, and Self-Employment: New Evidence from Brazil, Mexico, and South Africa. Review of Income and Wealth 57, 100-122.

CENTRAL, 2005. Plano Diretor de Transporte Urbano da Região Metropolitana do Rio de Janeiro: Resultatos da Pesquisa Origem e Destino. Rio de Janeiro: Governo do Estado do Rio de Janeiro.

Cervero, R., Wu, K. L., 1997. Polycentrism, commuting, and residential location in the San Francisco Bay area. Environment and Planning A 29(5), 865-886.

Cervero, R., 2001. Efficient urbanisation: economic performance and the shape of the metropolis. Urban Studies 38(10), 1651-1671.

Charron, M., 2007. From excess commuting to commuting possibilities: more extension to the concept of excess commuting. Environment and Planning A 39(5), 1238.

Dargay, J., Hanly, M., 2007. Volatility of car ownership, commuting mode and time in the UK. Transportation Research Part A: Policy and Practice 41(10), 934-948.

DeSouza, E. R., Baldwin, J., Koller, S. H., Narvaz, M., 2004. A Latin American perspective in the study of gender. In: Paludi, M.A. (Ed.), Praeger guide to the psychology of gender. Westport: Praeger Publishers, pp. 41-67.

De Miranda, R. A., Domingues, E. P., 2010. Commuting to work and residential choices in the metropolitan area of Belo Horizonte, Brazil. Urban Public Economics Review 12, 41-71.

Dejoux, V., Marin-Lamellet, C., 2010. Survey on people with travel difficulties in France. In Proceedings of 12th International Conference on Mobility and Transport for Elderly and Disabled Persons, HongKong: China.

Diaz Olvera, L., Plat, D., Pochet, P., 2013. The puzzle of mobility and access to the city in Sub-Saharan Africa. Journal of Transport Geography 32, 56-64. 
Dieleman, F. M., Dijst, M., Burghouwt, G., 2002. Urban form and travel behaviour: micro-level household attributes and residential context. Urban Studies 39(3), 507-527.

Fernández-Maldonado, A. M., Romein, A., Verkoren, O., Parente Paula Pessoa, R., 2013. Polycentric Structures in Latin American Metropolitan Areas: Identifying Employment Sub-centres. Regional Studies, 48(12), 1954-1971.

Garske, T., Yu, H., Peng, Z., Ye, M., Zhou, H., Cheng, X., ... \& Jones, J., 2011. Travel patterns in China. PloS one, 6(2), e16364.

Gascon, M.-O., Quetelard, B., Patiès, C., Valgalier, J.-L, 2009. Calcul a posteriori des distances dans les enquêtes ménages déplacements. Paris: CERTU.

Giuliano, G., Small, K. A., 1993. Is the journey to work explained by urban structure? Urban studies 30(9), 1485-1500.

Givoni, M., Banister, D., 2013. Moving towards low carbon mobility. Cheltenham, UK: Edward Elgar Publishing Limited.

Gutiérrez-i-Puigarnau, E., Van Ommeren, J. N., 2010. Labour supply and commuting. Journal of Urban Economics, 68(1), 82-89.

Hallak Neto, J., Namir, K., Kozovits, L., 2012. The informal sector and informal employment in Brazil: an analysis of the results of the new series from the national account system (2000/07). Economia e Sociedade 21 (1), 93-113.

Handy, S., 1996. Methodologies for exploring the link between urban form and travel behavior. Transportation Research Part D: Transport and Environment 1(2), 151-165.

Henley, A., Arabsheibani, G. R., Carneiro, F. G., 2009. On defining and measuring the informal sector: Evidence from Brazil. World Development 37 (5), 992-1003.

Hjorthol, R., Vågane, L., 2014. Allocation of tasks, arrangement of working hours and commuting in different Norwegian households. Journal of Transport Geography 35, 75-83.

Holden, M. E., 2012. Achieving sustainable mobility: everyday and leisure-time travel in the EU. Ashgate: Ashgate Publishing.

Holzer, H. J. 1991. The Spatial Mismatch Hypothesis: What Has the Evidence Shown? Urban Studies 28 (1), 105-122.

Horner, M. W., Murray, A. T., 2002. Excess commuting and the modifiable areal unit problem. Urban Studies 39(1), 131-139.

IBGE, 2013. Atlas do censo demográfico 2010. Rio de Janeiro: IBGE.

Ineri, M. C. 2011. Desigualdade de Renda na Década. Rio de Janeiro: CPS - FGV.

Jonasson, E. 2011. Informal Employment and the Role of Regional Governance. Review of Development Economics 15 (3), 429-441. 
Kain, J. F. 1968. Housing segregation, negro employment, and metropolitan decentralization. The Quarterly Journal of Economics 82 (2), 175-197.

Keeling, D. J., 2013. Transport research challenges in Latin America. Journal of Transport Geography 29, 103-104.

Kwan, M. P., 2000. Gender differences in space-time constraints. Area 32(2), 145-156.

Lau, C. Y., 2011. Spatial mismatch and the affordability of public transport for the poor in Singapore's new towns. Cities 28(3), 230-237.

Lee, B. S., McDonald, J. F., 2003. Determinants of commuting time and distance for Seoul residents: the impact of family status on the commuting of women. Urban Studies 40(7), 1283-1302.

Lucas, K., 2011. Making the connections between transport disadvantage and the social exclusion of low income populations in the Tshwane Region of South Africa. Journal of Transport Geography 19(6), 1320-1334.

Manning, A., Petrongolo, B., 2008. The Part-Time Pay Penalty for Women in Britain. The Economic Journal 118(526), F28-F51.

Maoh, H., Tang, Z., 2012. Determinants of normal and extreme commute distance in a sprawled midsize Canadian city: evidence from Windsor, Canada. Journal of Transport Geography 25, 50-57.

Marques, E., Scalon, C., Oliveira, M. A., 2008. A comparison of social structures in Rio de Janeiro and São Paulo. Dados 51 (1), 215-238.

Medeiros Junior, H. 2011. Distribuição dos empregos formais na cidade do Rio de Janeiro em 2008: uma análise espacial. Coleção Estudos Cariocas 2011, 1-26.

Mercado, R., Páez, A., 2009. Determinants of distance traveled with a focus on the elderly: a multilevel analysis in the Hamilton CMA, Canada. Journal of Transport Geography 17(1), 65-76.

Mitra, A., 2005. Women in the urban informal sector: Perpetuation of meagre earnings. Development and Change 36(2), 291-316.

Modarres, A., 2013. Commuting and energy consumption: toward an equitable transportation policy. Journal of Transport Geography 33, 240-249.

Morency, C., Paez, A., Roorda, M. J., Mercado, R., Farber, S., 2011. Distance traveled in three Canadian cities: Spatial analysis from the perspective of vulnerable population segments. Journal of Transport Geography 19, 39-50.

Motte-Baumvol, B., Nassi, C. D., 2012. Immobility in Rio de Janeiro, beyond poverty. Journal of Transport Geography 24, 67-76.

Naudé, W., 2008. Is there a spatial mismatch in South Africa's metropolitan labour market?. Cities 25(5), 268-276.

Neto, R. S., Duarte, G., Páez, A., 2014. Gender and commuting time in São Paulo Metropolitan Region. Urban Studies, forthcoming. 
Novaco, R. W., Gonzalez, O. I., 2009. Commuting and well-being. In: Yair Amichai-Hamburger (Ed.), Technology and well-being. Cambridge: Cambridge University Press, pp. 174-205.

OECD, 2014. How does Brazil compare? OECD Employment Outlook, September.

Peng, Z. R., 1997. The jobs-housing balance and urban commuting. Urban studies, 34(8), 1215-1235.

Pereira, R. H. M., and T. Schwanen. 2013. Tempo de deslocamento casa-trabalho no Brasil (1992-2009): Diferenças entre regiões metropolitanas, níveis de renda e sexo. Instituto de Pesquisa Econômica Aplicada (IPEA).

Plaut, P. O. 2006. The intra-household choices regarding commuting and housing. Transportation Research Part A: Policy and Practice 40(7), 561-571.

Punpuing, S. 1993. Correlates of commuting patterns: a case-study of Bangkok, Thailand. Urban Studies, 30(3), 527-545.

Ramos, L., and V. Ferreira. 2006. Padrões espacial e setorial da evolulccão da informalidade no período 1991-2005. Pesquisa e Planejamento Econômico 36 (3), 471-488.

Ramos, L. R. A. 2002. A evolução da informalidade no Brasil metropolitano: 1991-2001. Instituto de Pesquisa Econômica Aplicada (IPEA).

Ribeiro, L. C. D. Q., Lago, L. C. D., 1995. Restructuring in Large Brazilian Cities: The Centre/Periphery Model*. International Journal of Urban and Regional Research 19 (3), 369-382.

Rodrigues, J. M. 2013. Evolução da Frota de Automóveis e Motos no Brasil 2001-2012. Instituto Nacional de Ciências e Tecnologia. Rio de Janeiro: Observatório das Metrópoles.

Rodríguez Vignoli, J. 2008. Movilidad cotidiana, desigualdad social y segregación residencial en cuatro metrópolis de América Latina. EURE (Santiago) 34 (103), 49-71.

Rosseel, Y. 2012. lavaan: An R Package for Structural Equation Modeling. Journal of Statistical Software, 48(2), 1-36. URL http://www.jstatsoft.org/v48/i02/.

Rouwendal, J., Meijer, E., 2001. Preferences for housing, jobs, and commuting: a mixed logit analysis. Journal of regional science 41(3), 475-505.

Salon, D., Gulyani, S., 2010. Mobility, poverty, and gender: travel 'choices' of slum residents in Nairobi, Kenya. Transport Reviews, 30(5), 641-657.

Santos, G., Maoh, H., Potoglou, D., von Brunn, T., 2013. Factors influencing modal split of commuting journeys in medium-size European cities. Journal of Transport Geography 30, 127-137.

Sermons, M. W., Koppelman, F. S., 2001. Representing the differences between female and male commute behavior in residential location choice models. Journal of Transport Geography 9(2), 101110.

Shearmur, R., 2006. Travel from home: an economic geography of commuting distances in Montreal. Urban Geography 27(4), 330-359. 
Shirgaokar, M., (2014). Employment centers and travel behavior: exploring the work commute of Mumbai's rapidly motorizing middle class. Journal of Transport Geography, 41, 249-258.

Turner, T., Niemeier, D., 1997. Travel to work and household responsibility: new evidence. Transportation 24(4), 397-419.

Van Ommeren, J., Dargay, J., 2006. The optimal choice of commuting speed: consequences for commuting time, distance and costs. Journal of Transport Economics and Policy 40(2), 279-296.

Verhetsel, A., Vanelslander, T., 2010. What location policy can bring to sustainable commuting: an empirical study in Brussels and Flanders, Belgium. Journal of Transport Geography 18(6), 691-701.

Wang, F., 2001. Explaining intraurban variations of commuting by job proximity and workers' characteristics. Environment and Planning B 28(2), 169-182.

Wang, D., Chai, Y., 2009. The jobs-housing relationship and commuting in Beijing, China: the legacy of Danwei. Journal of Transport Geography 17(1), 30-38.

Watts, M. J., 2009. The impact of spatial imbalance and socioeconomic characteristics on average distance commuted in the Sydney metropolitan area.Urban Studies, 46(2), 317-339.

Yongling, Y., Guonan, Z., 2009. Empirical analysis of spatial mismatch of living-working: Based on a field survey in downtown Beijing. International Journal of Urban Sciences 13(1), 1-17.

Zhao, P., Lü, B., Roo, G. D., 2011. Impact of the jobs-housing balance on urban commuting in Beijing in the transformation era. Journal of transport geography 19(1), 59-69. 